\title{
The Effect of Perceived Quality, Customer Satisfaction, Corporate Image, Customer Experience on Customer Loyalty
}

\author{
Missy Salim ${ }^{1}$, Rodhiah ${ }^{2}$ \\ ${ }^{1,2}$ Universitas Tarumanagara, Indonesia \\ missy.115180129@stu.untar.ac.id,rodhiah@fe.untar.ac.id
}

\begin{abstract}
The purpose of this study was to examine the effect of perceived quality, customer satisfaction, corporate image and customer experience on customer loyalty. The population of this study are users of the LINE Webtoon application in Jakarta. This study uses a sample with a non-probability method. The sample selection technique is purposive sampling. The number of samples is 100 respondents who use the LINE Webtoon application. The data collection technique used a questionnaire distributed online via google form. The analysis technique uses SEM which is then processed with smartPLS. The results of this study indicate that perceived quality and customer experience have a positive and significant effect on customer loyalty. However, customer satisfaction and company image have no significant effect on customer loyalty.
\end{abstract}

\section{Keywords}

Perceived quality; customer satisfaction; company image; customer experience; customer loyalty

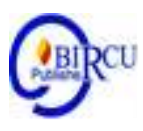

\section{Introduction}

Nowadays, the era continues to develop in many aspects, one of which is technology. The development of this technology is also supported by the internet which helps people to communicate remotely. In Indonesia alone, internet usage can be fairly high, where in early 2021 it reached 202.6 million people, an increase of $15.5 \%$ from the previous year. The percentage of internet penetration in Indonesia in early 2021 reached $73.7 \%$ of the current population of Indonesia, which is 274.9 million people with the most popular activity being social media, around 170 million people actively use social media (Kompas, 2021). Social media can be said to be a communication mechanism that allows its users to communicate with thousands, billions, and possibly all individuals around the world (Williams et al., 2012). Social media has also started to provide different services, namely digital comics, one of which is LINE Webtoon.

Customer loyalty is an important factor for a company including for LINE Webtoon. Products and services are no longer considered as an effective means to differentiate a company from its competitors, the most important differentiator is the existing customer loyalty (Kandampully et al, 2015). It is important for organizations to manage the quality of their services which are now considered a competitive advantage, this is because consumers have a perception of the products or services offered and these perceptions tend to be high (Wu, 2014). To maintain the loyalty of LINE Webtoon users, of course, one must pay attention to the quality of the comics and applications offered. (In Morgan \& Govender's research, (2017) it shows that there is no significant effect between perceived quality and customer loyalty, However, Prasadh's research (2018) shows that perceived quality has a significant positive effect on customer loyalty.

Development is a systematic and continuous effort made to realize something that is aspired. Development is a change towards improvement. Changes towards improvement require the mobilization of all human resources and reason to realize what is aspired. In 
addition, development is also very dependent on the availability of natural resource wealth. The availability of natural resources is one of the keys to economic growth in an area. (Shah, M. et al. 2020)

One of the strong predictors of loyalty is customer satisfaction itself (Loureiro et al., 2014). According to Hussain et al. (2015) to retain customers, of course, the company must have a positive image and tend to be attractive. Basically, forming a strong image is forming consumer confidence in the products and services provided (Thio \& Rodhiah, 2021). It is said that customer experience is a means to build a loyal customer base (Srivastava \& Kaul, 2016). In a previous study, Makanyeza \& Chikazhe, (2017) examined the relationship between service quality, customer satisfaction and corporate image on customer loyalty, but in Prasadh's research (2018) only examines the relationship of perceived quality to customer loyalty and customer satisfaction as a mediation in the banking sector with bank customer respondents in Zimbabwe. There is also research by Kamath et al, (2020) examining customer experience on loyalty mediated by brand equity and satisfaction in the banking industry with bank customers as respondents. In this study, researchers used perceived quality, customer satisfaction, corporate image, and customer experience as factors that influence customer loyalty at LINE Webtoon in Jakarta with LINE Webtoon users as respondents. (2020) examines customer experience on loyalty mediated by brand equity and satisfaction in the banking industry with bank customers as respondents. In this study, researchers used perceived quality, customer satisfaction, corporate image, and customer experience as factors that influence customer loyalty at LINE Webtoon in Jakarta with LINE Webtoon users as respondents. (2020) examines customer experience on loyalty mediated by brand equity and satisfaction in the banking industry with bank customers as respondents. In this study, researchers used perceived quality, customer satisfaction, corporate image, and customer experience as factors that influence customer loyalty at LINE Webtoon in Jakarta with LINE Webtoon users as respondents.

\section{Review of Literature}

\subsection{Perceived Quality}

Perceived quality is a form of assessment given by consumers by considering the advantages of the products and services offered (Snoj et al., 2004:159). The quality of the experience provided to customers builds buying habits, even though competition is very competitive and there are various similar offerings (Mainardes et al., 2019).

\subsection{Customer Satisfaction}

Oliver (2015:8) customer satisfaction is defined as the consumer's response and assessment of the products and services available related to fulfilling consumption that pleases customers. Assessment of the performance of a product is in accordance with what the buyer expects (Kotler \& Armstrong, 2012:13).

\subsection{Corporate Image}

Chi et al., (2018) corporate image can be defined as the stipulation of the code of ethics and values of a company that comes from the overall impression and perception of the internal and external environment of a company which is a comprehensive reflection of the company's status. Minkiewicz et al., (2011: 192)Corporate image widely used as a synonym for reputation, perception, cognition, attitude, trust, communication, message and credibility between customers and companies. 


\subsection{Customer Experience}

Lemke et al., (2011: 848) customer experience is defined as the experience experienced by clients in the form of quality that is superiority or greatness and also subjective reactions given by clients to direct or strange experiences with the company. Customer experience is understood as the total of all sentiments that have been experienced by customers at the point of contact between customers and the company (Sujata et al., 2014).

\subsection{Customer Loyalty}

Customer loyaltyis an attachment that exists between the customer and the company regarding the products and services offered by the company (Smith, 2020: 159). Casidy \& Wymer (2016: 196) customer loyalty is a feeling of attachment that is felt by the customer and is then shown to a onek loyalty compared to repeated commercial transactions.

\subsection{The Relationship between Perceived Quality and Customer Loyalty}

In Prasadh's research (2018) on e-banking, it is said that perceived quality has a significant positive effect on customer loyalty. According to research by Morgan \& Govender (2017) on cellular telecommunications, it says that there is no significant effect between perceived quality and customer loyalty.

\subsection{The Relationship between Customer Satisfaction and Customer Loyalty}

According to research Morgan \& Govender (2017) regarding cellular telecommunications show that customer satisfaction has a positive influence on customer loyalty. In the research of Haron et al, (2020) about Islamic banks, it shows that customer satisfaction significantly influences and has a positive effect on customer loyalty. According to research (Gardiazabal et al., 2020) about retail services, it shows that customer satisfaction has a positive influence on customer loyalty.

\subsection{The Relationship between Corporate Image and Customer Loyalty}

According to the research of Makanyeza \& Ckihazhe (2017) on the banking sector, it shows that corporate image positive effect on customer loyalty. In research (Özkan et al., 2020) about the banking industry in Turkey, it shows that corporate image has a positive influence on customer loyalty. In Wang \& Wu's (2012) research on hair salon customers, it shows that corporate image has a positive influence on customer loyalty.

\subsection{The Relationship between Customer Experience and Customer Loyalty}

According to research by Nobar \& Rostamzadeh (2018) about the hotel industry, it shows that customer experience has a positive influence on customer loyalty. According to (Kamath et al., 2020) regarding retail banks, it shows that customer experience has a positive influence on customer loyalty. In Makudza's (2020) research on the banking industry, it shows that customer experience has a positive influence on customer loyalty.

\subsection{Relevant Research}

In previous studies there were many researchers who had discussed the variables used in this study, one of which was Makanyeza \&ckihazhe, (2017) in a study on the banking sector consisting of 310 respondents who showed that service quality, customer satisfaction, corporate image had a direct influence on customer loyalty, not only that, it was also found that perceived quality was mediated by customer satisfaction and 
corporate image also had a positive influence. to customer loyalty.

It's also in Haron's research et al., (2020) which is still discussing the banking industry with 401 respondents found that customer loyalty mediated through trust has a positive effect on customer loyalty. Prasadh's research (2018) examines the effect of perceived quality on customer loyalty mediated by customer satisfaction who discusses ebanking. Researchers took 334 valid respondents from 450 respondents found that perceived quality directly affects customer loyalty, besides that perceived quality mediated by customer satisfaction also has a positive influence on customer loyalty.

\subsection{Framework}

Customers greatly determine the strength of a company to survive or not in the face of competitors. Customers play an important role in the survival of the company. Customers will remain loyal when their expectations for a product or service are appropriate, when these expectations are achieved, the customer will feel satisfied and remain loyal.

This study also discusses customer satisfaction. Customer satisfaction is a driving factor for customers to remain loyal to a brand. Customers will remain loyal to a brand when their expectations for the brand are met and provide maximum satisfaction for customers.

Furthermore, there is a corporate image which is an outward appearance but is quite influential for customer loyalty. When a company has a bad image, it will certainly cause doubts for the public about what the company has to offer. Conversely, when the company's image goes in a positive direction, it can certainly increase customer confidence in the products or services offered.

Finally, there is such a thing as customer experience. This experience can be in the form of direct or indirect experiences felt by customers, when customers are satisfied with their experience of a brand, they will of course remain loyal to the brand.

These four factors, namely perceived quality, customer satisfaction, corporate image and customer experience have a direct influence on customer loyalty.

Based on the statement above, the framework of thought formed is as follows:

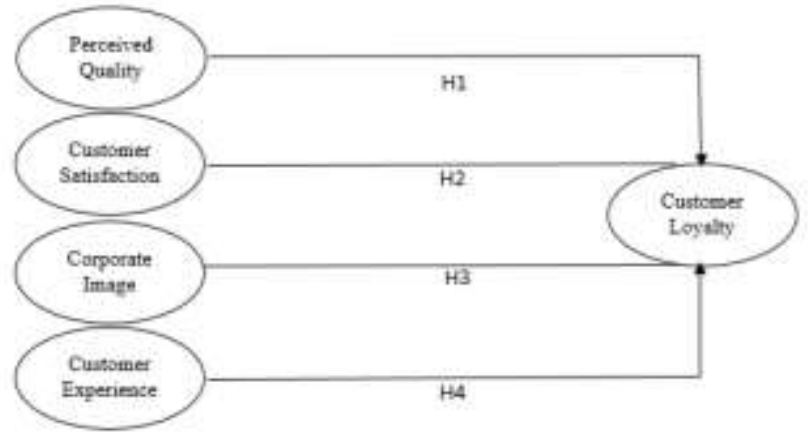

Figure 1. Framework

The hypotheses in this study are as follows:

H1: Perceived quality has a positive influence on customer loyalty.

H2: Customer satisfaction has a positive influence on customer loyalty.

H3: Corporate image has a positive influence on customer loyalty.

H4: Customer experience has a positive influence on customer loyalty. 


\section{Research Method}

The population in this study were users of the LINE Webtoon application in Jakarta. In this study, the sample selection technique used is a non-probability technique, namely purposive samplingsamplingwhere the sample is selected based on certain criteria, namely those who have used the LINE Webtoon application for at least 2 years with a total sample of 100 respondents.Data collection techniques using questionnaires distributed online via google form. The variables studied in this study are perceived quality, customer satisfaction, corporate image, and customer experience and customer loyalty. In this study, the analysis technique uses SEM which is then processed with smartPLS which consists of two analyzes in the form of inner model measurement and outer model measurement.

\section{Results and Discussion}

\subsection{Respondent Profile}

Based on the respondent's characteristics data, the majority of respondents are women $(73 \%)$, the last education is high school (75\%), then the majority of respondents are 21-25 years old (50\%), in addition to the occupation chosen by the majority of respondents are students $(83 \%)$ ), Then the monthly expenditure for the majority of respondents is $\mathrm{Rp} .0-\mathrm{Rp} .1,000,000(47 \%)$ and finally the majority of respondents are domiciled in West Jakarta (52\%).

\subsection{Analisis Results of Outer Model Measurement \\ a. Convergent Validity}

Table 1. Results of Analysis of Average Variance Extracted

\begin{tabular}{|l|c|}
\hline \multicolumn{1}{|c|}{ Variables / Dimensions } & Average Variance Extracted \\
\hline Perceived Quality & 0.518 \\
\hline Customer Satisfaction & 0.635 \\
\hline Corporate Image & 0.540 \\
\hline Customer Experience & 0.635 \\
\hline Customer Loyalty & 0.533 \\
\hline
\end{tabular}

Based on the results of the Average Variance Extracted analysis in table 1, it shows that each variable has a value of more than $0.50(>0.50)$. In this study the variables used have met the requirements seen from the results of the AVE through convergent validity

\section{b. Discriminant Validity}

Table 2. Results of Heterotrait Analysis - Monotrait Ratio (HTMT)

\begin{tabular}{|l|l|l|l|l|l|}
\hline Variable & $\begin{array}{l}\text { Corporate } \\
\text { Image }\end{array}$ & $\begin{array}{l}\text { Customer } \\
\text { Experience }\end{array}$ & $\begin{array}{l}\text { Customer } \\
\text { Loyalty }\end{array}$ & $\begin{array}{l}\text { Customer } \\
\text { Satisfaction }\end{array}$ & $\begin{array}{l}\text { Perceived } \\
\text { Quality }\end{array}$ \\
\hline $\begin{array}{l}\text { Corporate } \\
\text { Image }\end{array}$ & & & & & \\
\hline $\begin{array}{l}\text { Customer } \\
\text { Experience }\end{array}$ & 0.753 & & & & \\
\hline $\begin{array}{l}\text { Customer } \\
\text { Loyalty }\end{array}$ & 0.555 & 0.730 & & & \\
\hline Customer & 0.848 & 0.830 & 0.579 & & \\
\hline
\end{tabular}




\begin{tabular}{|l|l|l|l|l|l|}
\hline Satisfaction & & & & & \\
\hline $\begin{array}{l}\text { Perceived } \\
\text { Quality }\end{array}$ & 0.763 & 0.711 & 0.774 & 0.806 & \\
\hline
\end{tabular}

Based on the results of the Heterotrait-Monotrait Ratio in table 2 shows that all indicators already have a value less than $0.9(<0.9)$ so it can be said that the indicators used have met the requirements.

\section{c) Reliability}

Table 3. Analysis Results Composite Reliability and Coeficient Cronbach's Alpha

\begin{tabular}{||c||c||c|}
\hline Variables / Dimensions & Composite Reliability & $\begin{array}{c}\text { Coefficient Cronbach's } \\
\text { Alpha }\end{array}$ \\
\hline \hline Perceived Quality & 0.761 & 0.560 \\
\hline \hline Customer Satisfaction & 0.897 & 0.858 \\
\hline \hline Corporate Image & 0.823 & 0.720 \\
\hline \hline Customer Experience & 0.873 & 0.829 \\
\hline \hline Customer Loyalty & 0.871 & 0.823 \\
\hline \hline
\end{tabular}

Based on the results of the analysis of composite reliability and Cronbach's alpha coefficient in table 3 , it shows the composite reliability value of each variable in this study has a value of more than 0.7 (>0.7) which indicates that the indicators used to measure the variables used in this study are reliable and reliable because they have value greater than 0.7. The results of the analysis of the cronbach's alpha coefficient show a value of more than $0.4(>0.4)$ which indicates that the cronbach's alpha coefficient is quite reliable, there is also one that shows more than $0.6(>0.6)$ which indicates the cronbach's alpha coefficient is reliable.

\subsection{Result of Inner Model Measurement \\ a. R-Square (R2) analysis}

Table 4.The analysis results of the R-Square (R2)

\begin{tabular}{|c|c|c|}
\hline Variable & R-square & Description \\
\hline Customer Loyalty & 0.475 & Small \\
\hline
\end{tabular}

Based on the results of the r-square analysis in table 4 , it can be seen that the r-square value is 0.475 which explains that $47.5 \%$ of the customer loyalty variable can be explained by the perceived quality, customer satisfaction, corporate image and customer experience variables. While the remaining $52.5 \%$ can be explained by variables not examined in this study. From these results it can be concluded that perceived quality, customer satisfaction, company image and customer experience variables perceived quality, customer satisfaction, corporate image and customer experience have a small level of influence on the customer 
loyalty variable because the value of the determinant coefficient obtained is 0.475 which is between 0.25 and 0.5 .

b) Test of predictive relevance $(\mathbf{Q} 2)$

Table 5. Predictive relevance test results (Q2)

\begin{tabular}{|c|c|}
\hline Variable & $\mathbf{Q}^{\mathbf{2}}$ \\
\hline Customer loyalty & 0.225 \\
\hline
\end{tabular}

Based on the results of the analysis of predictive relevance $\left(\mathrm{Q}^{2}\right)$ in table 5, explaining the relationship between the constructs of each variable studied in this study is considered relevant to measure the research model that has been well formed, because the value of $\mathrm{Q}^{2}$ in this study is greater than $0(>0)$ which is 0.225 .

c) Hypothesis Test

Table 6. Hypothesis Test Results

\begin{tabular}{|c|c|c|}
\hline Variable & Mark & Description \\
\hline Perceived Quality $\rightarrow$ Customer Loyalty & $\begin{array}{l}\square: 0.349 \\
p \text {-value: } 0.000 \\
\mathrm{f}^{2}: 0.150\end{array}$ & $\begin{array}{c}\text { Positive } \\
\text { Significant } \\
\text { Medium Effect }\end{array}$ \\
\hline $\begin{array}{c}\text { Customer Satisfaction } \rightarrow \text { Customer } \\
\text { Loyalty }\end{array}$ & $\begin{array}{l}\square:-0.022 \\
p \text {-value }: 0.880 \\
\mathrm{f}^{2}: 0.000\end{array}$ & $\begin{array}{c}\text { Negative } \\
\text { Not significant } \\
\text { Minor Effect }\end{array}$ \\
\hline Corporate Image $\rightarrow$ Customer Loyalty & $\begin{array}{l}\square: 0.064 \\
p \text {-value: } 0.639 \\
\mathrm{f}^{2}: 0.004\end{array}$ & $\begin{array}{c}\text { Positive } \\
\text { Not significant } \\
\text { Minor Effect }\end{array}$ \\
\hline $\begin{array}{c}\text { Customer Experience } \rightarrow \text { Customer } \\
\text { Loyalty }\end{array}$ & $\begin{array}{l}\square: 0.420 \\
p \text {-value: } 0.000 \\
\mathrm{f}^{2}: 0.162\end{array}$ & $\begin{array}{c}\text { Positive } \\
\text { Significant } \\
\text { Medium Effect }\end{array}$ \\
\hline
\end{tabular}

Based on the results of hypothesis testing in table 6 , it shows that perceived quality and customer experience have a positive, significant effect, with a moderate effect on customer loyalty. Furthermore, it can be seen that customer satisfaction has a negative, insignificant effect, with a small effect on customer loyalty and corporate image has a positive, insignificant effect, with a small effect on customer loyalty.

Hypothesis Test Results 1: Perceived quality has a positive influence on customer loyalty, meaning that $\mathrm{H} 1$ is accepted.

Hypothesis Test Results 2: Customer Satisfaction has a positive influence on customer loyalty, meaning that $\mathrm{H} 2$ is not accepted.

Hypothesis Test Results 3: Corporate image has a positive influence on customer loyalty, meaning that $\mathrm{H} 2$ is not accepted.

Hypothesis Test Results 4: customer experience has a positive influence on customer loyalty, meaning that $\mathrm{H} 4$ is accepted. 
d) Test Goodness of Fit (GoF)

Table 7. Goodness of fit test results $(\mathrm{GoF})$

\begin{tabular}{|c|c|c|c|}
\hline Variable & AVE & $\mathrm{R}^{2}$ & $\begin{array}{l}\text { Goodness of Fit } \\
(\text { GoF })\end{array}$ \\
\hline Perceived Quality & 0.518 & & \\
\hline Customer Satisfaction & 0.635 & & \\
\hline Corporate Image & 0.540 & & \\
\hline Customer Experience & 0.635 & & \\
\hline Customer Loyalty & 0.533 & 0.475 & \\
\hline Average & 0.572 & 0.475 & 0.521 \\
\hline
\end{tabular}

Formula:

$$
\begin{aligned}
& \text { Gof: } \sqrt{\overline{A V E} \times \overline{R^{2}}} \\
& : \sqrt{0,572 \times 0,475} \\
& : 0.521
\end{aligned}
$$

Based on table 7 shows the results of the goodness of fit test of 0.521 which is included in the medium category. So it can be concluded that the model used in this study has a good fit.

\subsection{Discussion}

Based on the first hypothesis, it shows that perceived quality has a positive, significant effect on customer loyalty, so from these results it can be concluded that $\mathrm{H} 1$ is accepted. This is in line with researchPrasadh (2018) regarding e-banking says that perceived quality has a significant positive effect on customer loyalty, but it is not in line with researchMorgan \& Govender (2017) regarding cellular telecommunications which says that there is no significant effect between perceived quality and customer loyalty. Next, test the second hypothesis, showing that customer satisfaction has a negative and insignificant effect on customer loyalty, so from these results it can be concluded that $\mathrm{H} 2$ is not accepted. This is not in line with previous research (Morgan \& Govender, 2017; Haron et al, 2020; Gardiazabal et al., 2020) which states that customer satisfaction has a positive influence on customer loyalty. This shows that customer satisfaction has a positive effect on customer loyalty only in a few studies, such as research on cellular telecommunications, Islamic banks and retail services. but does not apply to the LINE Webtoon application. Based on the fourth hypothesis test, it shows that corporate image does not have a positive and significant effect on customer loyalty, so from these results it can be concluded that $\mathrm{h} 3$ is not accepted. This is not in line with previous research (Nobar \& Rostamzadeh, 2018; Kamath et al., 2020; Makudza, 2020) which stated that corporate image has a positive influence on customer loyalty. Previous research on the banking sector (Nobar \& Rostamzadeh, 2018), on the banking industry (Kamath et al., 2020) and on hair salons (Makudza, 2020). This shows that corporate image has a positive effect on customer loyalty only in a few studies, such as research on the banking sector, banking industry and also about hair salons, but this does not apply to the LINE Webtoon application. Finally, the results of the fourth hypothesis test, indicate that customer experience has a positive 
and significant influence on customer loyalty, so from these results it can be concluded that H4 is accepted. This is in line with previous research (Nobar \& Rostamzadeh, 2018; Kamath et al., 2020; Makudza, 2020) which stated that customer experience has a positive influence on customer loyalty.

\section{Conclusion}

Based on the results of data processing that has been carried out and the conclusions that have been explained, it can be concluded that perceived quality and customer experience have a positive influence on customer loyalty, but customer satisfaction and corporate image do not have a positive influence on customer loyalty. For further research, it is hoped that the number of samples can be more and wider, not only in Jakarta, but can take samples from other cities and are expected to be able to conduct research on similar topics in other industries.

\section{References}

Ajzen, I. (1991). The Theory of Planned Behavior. Organizational Behavior and Human Decision Processes, 50(2), 79-211.

Casidy, R. \& Wymer, W. (2016). Journal of Retailing and Consumer Services A risk worth taking: Perceived risk as moderator of satisfaction, loyalty, and willingnessto-pay premium price. Journal of Retailing and Consumer Services, 32, 189-197. https://doi.org/10.1016/j.jretconser.2016.06.014.

Chi, H., Yeh, H. \& Guo, T. (2018). Salary or job interest? How salary and job interest moderates the willingness to apply for a job. Journal of Business Administration 10(1), 64-78.

Fishbein, M., and Ajzen, 1. 1975. Belief, attitude, intention, and behavior: An introduction to theory and research, Reading, MA: Addison.Wesley.

Gardiazabal, P., Bianchi, C. \& Saleh, M. A. (2020). The transformational potential of Latin American retail experiences. Journal of Services Marketing, 34(6), 769-783.

Haron, R., Subar, N. A. \& Ibrahim, K. (2020). Service quality of Islamic banks: satisfaction, loyalty and the mediating role of trust. Islamic Economic Studies 28(1), 3-23.

Hussain, R., Nasser, A.A. and Hussain, Y.K. (2015). Service quality and customer satisfaction of a UAE-based airline: an empirical investigation. Journal of Air Transport Management, 42(1), 167-175.

Kamath, P. R., Pai, Y. P., \& Prabhu, N. K. P. (2020). Building customer loyaltyin retail banking: a serial-mediation approach. International Journal of Bank Marketing, 38(2), 456-484.

Kandampully, J., Zhang, T. \& Bilgihan, A. (2015). Customer loyalty: A review and future directions with a special focus on the hospitality industry. International Journal of Contemporary Hospitality Management, 27(3), 379-414.

Kompas. (2021). Jumlah Pengguna Internet Indonesia 2021 Tembus 202 Juta. https://tekno.kompas.com/read/2021/02/23/16100057/jumlah-pengguna-internet indonesia-2021-tembus-202-juta. Diakses pada 20 September 2021.

Kotler, P. \& Armstrong, G. 2012. Principles of Marketing. New Jersey: Prentice Hall.

Lemke, F., Clark, M., \& Wilson, H. (2011). Customer experience quality: an exploration in business and consumer contexts using repertory grid technique. Journal of the 
Academy of Marketing Science, 39(6), 846-869.

Loureiro, S. M. C., Miranda. F. J. \& Breazeale, M. (2014). Who Needs Delight? The Greater Impact of Value, Trust and Satisfaction in Utilitarian, Frequent-Use Retail. Journal of Service Management, 25(1), 101-124.

Mainardes, E. W., Gomes, V. C. A., Marchiori, D., Correa, L. E. \& Guss, V. (2019). Consequences of customer experience quality on franchises and non-franchises models. International Journal of Retail \& Distribution Management 47(3), 311-33. DOI 10.1108/IJRDM-09-2018-0211

Makanyeza,C. \& Chikazhe, L. (2017). Mediators of the relationship between service quality and customer loyalty Evidence from the banking sector in Zimbabwe. International Journal of Bank Marketing, 35(3), 540-556.

Makudza,F. (2020) Augmenting customer loyalty through customer experience management in the banking industry. Journal of Asian Business and Economic Studies 28(3), 191-203. DOI 10.1108/JABES-01-2020-0007.

Minkiewicz, J., Evans, J., Bridson, K. \& Mavondo, F. (2011). Corporate image in the leisure services sector. Journal of Services Marketing, 25(3), 190-201.

Morgan, S. \& Govender, K. (2017). Exploring customer loyalty in the South African mobile telecommunications sector. Cogent Business \& Management, 4(1), 1273816.

Nobar, H. B. K. \& Rostamzadeh, R. (2018). The impact of customer satisfaction, customer experience and customer loyalty on brand power: Empirical evidence from hotel industry. Journal of Business Economics and Management, 19(2), 417-130.

Oliver, R. L. (2015). Satisfaction a behavioral perspective on the customer (10th ed.). Routledge.

Özkan, Pınar; Süer, Seda; Keser, İstem Köymen; İpek Deveci Kocakoç. (2020). The effect of service quality and customer satisfaction on customer loyalty: The mediation of perceived value of services, corporate image, and corporate reputation, 38(2), 384405. DOI: 10.1108 .

Prasadh, R.R. (2018). Examining The Roles of Perceived Quality and Customer Satisfaction as Predictors of Customer Loyalty in The Indian E-Banking Context. Journal of Management Research, 18(3), 176-187.

Shah, M. et al. (2020). The Development Impact of PT. Medco E \& P Malaka on Economic Aspects in East Aceh Regency. Budapest International Research and Critics Institute-Journal (BIRCI-Journal). P. 276-286.

Smith, T. A. (2020). The role of customer personality in satisfaction, attitude-tobrand and loyalty in mobile services. Spanish Journal of Marketing - ESIC, 24(2), 155-175.

Snoj, B., Pisnik Korda, A. and Mumel, D. (2004). The relationships among perceived quality, perceived risk and perceived product value. Journal of Product \& Brand Management, 13(3), 156-167.

Srivastava, M. \& Kaul, D. (2016). Exploring the link between customer experienceloyalty-consumer spend. Journal of Retailing and Consumer Services, 31, 277-286.

Sujata, J., Saksham, S. M. \& Tanvi, G. (2014). Developing Smart Cities: An Integrated Framework. Procedia Computer Science, 93,902-909.

Thio, J. Y. \& Rodhiah. (2021). Pengaruh Service Encounter Quality, Brand Attitude, Image, Trust Terhadap Customer Loyalty Di Garuda Indonesia. Jurnal Manajerial dan Kewirausahaan. 3, (4), 1019-1028.

Wang, C-Y. \& Wu, L-W. (2012). Customer loyalty and the role of relationship length. Managing Service Quality, 22(1), 58-74.

Williams, S. G. (2012). The Ethics of Internet Research. Online Journal of Nursing 
Informatics, $16(2)$.

Wu, H.C. (2014). The effects of customer satisfaction, perceived value, corporate image and service quality on behavioural intentions in gaming establishments. Asia Pacific Journal of Marketing and Logistics, 26(4), 540-565. 